\title{
LEARNING ENTREPRENEURSHIP FROM A CONSTRUCTIVIST PERSPECTIVE
}

\author{
Helge Löbler \\ University of Leipzig
}

\begin{abstract}
The aim of this article is to present a learning theory (constructivist theory) that supports and explains a lot of the requested changes in entrepreneurship education. It also explains how entrepreneurs learn and serves as a basis for designing entrepreneurship programs. If we look at the 'skills' and competencies of entrepreneurs from a constructivist's perspective we find most of them by observing children under the age of five or six: they are motivated to learn, they are interested in a variety of different topics, they ask excellent questions, they try many things to get insights, they are creative, they are impatient. In short, they create and govern their own learning process, which is open for any content, style, goal, experience, etc., and allows them to take every opportunity to answer the question in concern. In this sense it is similar to the entrepreneurial process where the entrepreneur tries everything and is ready to learn what is needed to be successful.
\end{abstract}




\section{Introduction}

I felt attracted to the field of economics very early, having started to invest my pocket money in the stock market at the age of 14. My family and teachers disapproved, since at that time it was regarded as an inappropriate and evil activity. Naturally I went on to study economics. To my surprise, the subject that I had experienced as being so exciting and breathtaking, at university turned out to be boring and meaningless. ${ }^{1}$

Could this not be the statement of any entrepreneur in the western world? Fiet ${ }^{2}$ addressed the question: why do students think that lectures or even school are boring or irrelevant? He proposes a student-approved system for class meetings that requires theory-based activities for the students. However, for entrepreneurs in particular, their business environment is characterized by diversity and ongoing change. In this environment entrepreneurs cannot always use given 'roadmaps' from management and entrepreneurship textbooks or from education to learn good decision making and to lead and manage their start-ups or ventures. In times of change they often have to create their own, new 'roadmaps' to find their way through unknown territory. In addition, in uncertain business environments, many questions concerning where and how to lead the venture cannot be answered by past experience. The answers have to be generated anew by the entrepreneur. In this world entrepreneurs have to learn more about learning than they do about their special subject. The present paper proposes that traditional management education focuses very much on a content driven education and on understanding existing 'roadmaps'. This has already been addressed and changed in entrepreneurship education. To create and invent new 'roadmaps' for unknown territories, entrepreneurship education should take into account more and more a process driven pedagogy with an open learning process. This also means that common knowledge is questioned by the learners. Questioning common knowledge is the starting point for creating new knowledge and therefore making new 'roadmaps'. Maybe it is also the starting point for what Schumpeter called a 'creative destruction'.

Self-reliance and independent thinking is also supported if a learner finds their idea valuable even if it does not fit into the common knowledge. To support creative destructions a bundle of competencies, skills and characteristics is needed.

Surprisingly or not, if we look carefully at children under the age of five or six we find several entrepreneurial competencies to start a creative destruction. They are motivated to learn, they are interested in many different topics, they do not care about conventions, they ask excellent questions, they discover exciting things, they are impatient and so on. Then they go to school and seem to unlearn these competencies. We will present a pedagogic approach that strongly supports these competencies, because in this approach (as described later) learning is seen as an open process that can lead to a creative destruction. We think that the openness of the learning process is the most important issue in entrepreneurship education because as an anonymous referee puts it, 'We don't know what makes a good entrepreneur so we should not pretend to'. From our perspective learning means to discover oneself and to develop oneself (which can of course be supported by teachers) and we think that this holds true particularly for entrepreneurs. To support this way of learning we obviously need an open learning process, which can be described by the six dimensions of the pedagogic space. ${ }^{3}$ From this six dimensions Alberti et al. ${ }^{4}$ took five key issues for entrepreneurship education and split the persons involved into audiences and educators, leading to six key issues. We also use these six key issues to describe different approaches in education, especially entrepreneurship education. The dimensions and the questions behind the dimensions are: 
- Educational goal

- What are the goals of the learning process and who does develop these goals?

- Educational content

- Where does the content come from and who decides about the content to be used?

$\circ$ How is the available content embedded in the learning process?

- Teachers (educators)

- What is the role of the teacher?

- Who governs the learning process, teacher or student?

- Learners (audiences)

$\circ \quad$ What is the role of the learner?

- Who governs the learning process, teacher or student?

- Assessment

- Pedagogy

- What is the general idea of 'teaching', 'knowledge' and 'information'?

- Who is interacting with whom during the learning process and what are the main activities?

$\circ$ Sources of information and inducement for getting information.

With these questions in mind we will show that there is a demand for a new or even different entrepreneurship education approach/paradigm where we think that the constructivist view can serve as a theoretical underpinning. We describe this demand, as discussed in the entrepreneurship education literature, in Section 2 by following the abovementioned questions, discussing some of them in more detail. In Section 3 we describe the constructivist approach by contrasting it with the very common transmission approach. We first describe the transmission approach and its weaknesses for entrepreneurship education in Section 3.1 and in Section 3.2 we explain the constructivist approach. Here again we use the aforementioned questions to contrast the two views.

It is important to notice that the constructivist approach needs a special learning environment that has to be created by the teacher. Using the constructivist approach the role of the teacher is totally different: For example the teacher is not the governor of the students learning process but rather a supporter of the learning process governed by the students (for details see Section 3 ). Because the environment plays an important role in the constructivist approach it is described in detail in Section 4. Now having a paradigm that serves as a theoretical base (from Section 3.2.) and knowing that the required learning environment is feasible (Section 4), we derive 10 principles for designing an entrepreneurship education program in Section 5. We have used and evaluated these principles for designing a one-semester entrepreneurship program. ${ }^{5}$

\section{Demands for Entrepreneurship Education}

The introduction of The International Journal of Entrepreneurship Education in 2002 shows the growing importance of this topic over the last two decades. It is already impossible to give an extensive overview of the entrepreneurship education literature. For good reviews, see Solomon et al., ${ }^{6}$ Kuratko, ${ }^{7}$ Katz,${ }^{8}$ Alberti ${ }^{9}$ and, especially for youth education, see Rasheed. ${ }^{10}$ In their article, Solomon et al. reviewed 240 programs of entrepreneurship education in the USA and took a closer look at in-class pedagogical methods. The creation of a business plan is the dominant method followed by case studies and lectures. In addition, Solomon et al. analyzed the external classroom pedagogical methods and they found that consulting small businesses and internships are the dominant methods outside the classroom. 
Are these methods supportive for entrepreneurial characteristics and competencies? 'Although prior research has debated whether entrepreneurial characteristics are innate, recent findings support the idea that psychological attributes can be culturally and experientially acquired. ${ }^{\prime 11}$

There are also hints that formal education does not foster entrepreneurial competencies and perhaps suppresses entrepreneurial attitudes. ${ }^{12}$ If entrepreneurial characteristics are fostered by experiential learning and are suppressed by formal education we would expect that children before they go to school would show a more entrepreneurial spirit compared to high school students. This was found by Kourilsky, ${ }^{13}$ who pointed out that $25 \%$ of kindergarten children showed important entrepreneurial characteristics compared to only $3 \%$ of high school students. If so, what happens at high school and university and more importantly what changes are recommended or demanded in the entrepreneurship education literature?

\section{Who Should Govern the Learning Process?}

In classical business education the learning process is very often governed by teachers and their syllabi. This approach is very much challenged in the entrepreneurship education literature-'the question for educators faced with ensuring students mastery is not, "What am I going to teach today?" but "What am I going to have my students do today?".14 The reasoning is also mentioned: "For studententrepreneurs to master a competency in the classroom, they must be fully engaged in activities that will teach it to them. ${ }^{15}$ This does not mean to hand over the steering-wheel totally to the student, it only means that the teacher is accepted by the students because '..., the most effective method is to establish a student-approved system for class meetings that require students to practice specific skills until they become competencies. ${ }^{16}$ Going further in the students' direction it was argued by Krueger and Brazeal, ${ }^{17}$ Kourilsky and Walstad, ${ }^{18}$ Gorman et al. ${ }^{19}$ that if entrepreneurship education is constructed in a learning oriented way instead of teaching oriented way, it would promote entrepreneurial characteristics. This does not necessarily mean that the students govern the learning process. The teacher could also govern it, according to the students learning progress, but 'as educators move away from tests in favor of self-directed "project" centered educational techniques ..., it makes sense to create a class structure that facilitates this form of learning' ${ }^{20}$ In this way, teachers would put students into the 'driver's seat' and let them play a more self-governed role. The more the students take over a self-governing role the more it changes the role of the teacher. The teacher will become the 'assistant' or coach of the student in the learning process whereas the student will become an active producer of knowledge while governing the learning process. However, if the student and not the teacher governs the learning process, what learning goals should be set by whom?

\section{Learning Goals}

In the classical business education transferring knowledge is one of the main goals. Students should gather a broad and deep base of knowledge that they then can apply to their work. In entrepreneurship education literature it was argued that entrepreneurs have to build a sense of community and that 'learning to live as a part of a community that is disperse, asynchronous and diverse is one of the initiatives that shapes character as well as knowledge'. ${ }^{21}$ We believe that entrepreneurs are selfgoverned people who reach their goals within their community. Moreover, they set their own goals in an uncertain environment. Therefore, 'students must be prepared to thrive in the unstructured and uncertain nature of entrepreneurial environments'.$^{22} \mathrm{~A}$ way to support these learning goals is to start early but carefully during the learning process by exposing the students to an uncertain and unstructured learning environment. For example, in one of our courses entitled 'Visions for Leipzig' 
the students came up with their own vision 'Leipzig inspires'. They organized and structured their project and learned what was necessary to govern the project. They convinced Leipzig's mayor to become the project's patron. They recruited their own sponsors to supply office equipment and PCs and began an advertising campaign. They even persuaded BMW to provide a Mini for the project. The course finished in February 2005 but the project was still running in fall 2005. Whenever the students asked for support we supported them, but they had to ask first. We never supported them if it was not really needed. At the beginning they had a lot of questions but we never gave them an answer. We only opened opportunities to figure out an answer that then became their own answer. In the feedback sessions students pointed out that they learned much more compared to classical courses. They were more involved and enthusiastic and worked much harder, because it was their own project driven by their own goals that they worked toward in their own way. The support we gave had therefore a different quality.

\section{Information and Activities}

Looking at entrepreneurs and how they adjust their beliefs Parker ${ }^{23}$ found that entrepreneurs learn only up to $20 \%$ based on new information but up to $80 \%$ based on former experience. While information can be gathered by listening and reading, experience can only be gathered by doing, thinking, talking, etc. The learner has to play an active role in gaining experience from their activities. They have to reflect on their activities andtheir outcomes. During the reflection process the teacher can play an important role not by giving answers to the student but by supporting them to find their way. Also peers can play an important role during the reflection process. Hereby the student can use all information available in the world, but 'the real issue is not technology-the hardware is going to change-but the interactive nature of the education' ${ }^{24}$. Darling-Hammond expressed her view, that

technology will support individuals becoming citizens of the world. Teachers will become coaches, directing students to the resources they need to solve problems - a guide on the side; helping students find answers online rather than a sage on stage. Teachers will understand how students are learning and access lots of different ways to have a particular student learn.

The interactive nature of this way of learning ensures that the students have to argue their concepts. During the arguing process the concept may be changed but becomes more and more the students own concept on which they can rely. Therefore we support sociocognitive conflict between students.

Table 1 shows, with some risk of oversimplification, the differences between 'old' business education and the postulations for 'good' entrepreneurship education as cited above, according to different criteria. It may be overstated a little bit but the differences should become apparent. Our assumption is that behind the two ways of 'teaching' there are two different education/learning paradigms. 
Table 1. Comparison of business education and entrepreneurial education

\begin{tabular}{|c|c|c|c|}
\hline & Business education & $\begin{array}{l}\text { Entrepreneurship } \\
\text { education }\end{array}$ & Author \\
\hline Focus on & Knowledge & Process & Fiet (Ref. 2) \\
\hline Teaching & $\begin{array}{l}\text { Transferring } \\
\text { knowledge }\end{array}$ & Supporting learning & $\begin{array}{l}\text { Darling-Hammond } \\
\text { (Ref. 25) }\end{array}$ \\
\hline Goal of education & Broad knowledge & $\begin{array}{l}\text { Learning to live, } \\
\text { autonomy, the ability } \\
\text { of self-governing }\end{array}$ & Stevenson (Ref. 21) \\
\hline Role of learner & Passive consumer & Active producer & Fiet (Ref. 44) \\
\hline Role of teacher & $\begin{array}{l}\text { Transmitter of } \\
\text { content }\end{array}$ & Assistant of the learner & Fiet (Ref. 44) \\
\hline $\begin{array}{l}\text { Sources of } \\
\text { information }\end{array}$ & Teacher, Textbooks & All sources available & Solomon et al. (Ref. 6) \\
\hline $\begin{array}{l}\text { Inducement for } \\
\text { getting information }\end{array}$ & $\begin{array}{l}\text { Teacher, } \\
\text { curriculum }\end{array}$ & Student's demand & Fiet (Ref. 44) \\
\hline $\begin{array}{c}\text { Who is governing the } \\
\text { learning process? }\end{array}$ & Teacher & Student & $\begin{array}{l}\text { Solomon et al. } \\
\text { (Ref. 6), Fiet } \\
\text { (Ref. 44), Darling- } \\
\text { Hammond (Ref. 25) }\end{array}$ \\
\hline Interaction between & Teacher, Student & $\begin{array}{l}\text { Students, teacher is not } \\
\text { excluded }\end{array}$ & Cantwell (Ref. 24) \\
\hline Activities & Listening, reading & Doing, thinking, talking & Fiet (Ref. 44) \\
\hline
\end{tabular}

\section{A New Paradigm?}

Do these changes call for a new paradigm in entrepreneurship education? We believe that this paradigm already exists, but has not yet been used in the field of entrepreneurship education. We also think that there is a demand for a new paradigm in entrepreneurship education. Some articulate it indirectly:

There can be no lethargy if we are to move the entrepreneurship cause to the next level. The skeptics are still alive and well. Renewed energy is needed to stimulate institutions reform and continue to establish entrepreneurship education legitimacy. We need to attract and develop the next generation of teachers. ${ }^{26}$

Some articulate it more directly:

It has been said that one definition of insanity is doing the same things and expatiating different results. Therefore, the emerging generation of entrepreneurship educators must avoid the paradigm paralysis that has consumed so many business disciplines. John Maynard Keynes said: 'The greatest difficulty in the world is not for people to accept new ideas, but to make them forget about old ideas'. ${ }^{27}$

Therefore a new paradigm that puts together all the pieces of the puzzle may be helpful in forgetting old ideas about teaching and furthermore it can serve as a conceptual underpinning of entrepreneurship education. 'Assessed as a whole, with some risk of oversimplification, it can be argued that the field's emphasis has been-pragmatically-more about entrepreneurial didactics and much less on developing their conceptual underpinnings' ${ }^{28}$ 
Therefore we will present the constructivist paradigm as it has already been discussed in the education literature because we think that it is very appropriate to be used in entrepreneurship education. In the next section we discuss the constructivist paradigm by contrasting it to the 'classical transmission' approach. In addition we also discuss the question: what is the general idea about 'teaching' in this paradigm?

\section{Two Views of Education}

\subsection{The Transmission Approach and its Problems}

Education is not only a well-defined technical term but also a common place for many ideas including training, teaching and learning, competencies and several other accomplishments. The word 'education' comes from the Latin 'ex-ducere' meaning 'to lead out'. The word 'duke' (a leader of men) also has the same origin. Therefore when we speak of the learning process, what educators are (or should be) doing is leading the knowledge out of the learner rather than imposing knowledge. One important distinction to be made asks whether things to be learned can be generated more or less logically by individual thought or whether they cannot be derived in this way.

If, for example, you want to get a driving license in continental Europe, you have to learn that one has to drive on the right side of the road. 'Why not drive on the left?' would be a pointless question, because you have to conform to a social convention for which there is no further explanation. In contrast the fact that the numbers two and two yield four when they are added can be worked out and checked by everyone who has learned to count. It does require knowledge of the conventional number words but from then on it is a question of conceiving units and mentally operating with them. ${ }^{29}$

We would typically say that it is a matter of fact that we drive on the right in central Europe and, for example, on the left in Great Britain. It is exactly the word 'fact', which stems from the Latin word 'facere' (to make) that shows us it is a social convention, which was established by the social and political process. Whether we drive on the right or the left cannot be derived by rational thinking. This kind of knowledge is usually obtained by the traditional direct transfer approach. We have to take it from other people because they have agreed upon it and so it can be judged as correct. The traditional direct transfer approach is directly linked to behaviorism. The teacher gives a stimulus (question) and the organism (students) has to give the (right) response (answer).

Our schools have centuries of experience with methods that are apt to bring about these kinds of learning [direct transfer approach, the author] more or less successfully. It is indeed the form of learning that is generally preferred. It is preferred for the simple reason that its results are easy to test. When students can repeat something verbatim, it is obvious that they have learned it-whether they have understood it, is a question these tests avoid. ${ }^{30}$

All teachers would agree 'that the deeper purpose of school is to foster independent thinking', but can we figure it out with the test?

'Last year,' a colleague of mine told me, 'I had an excellent student join my course in market research. He gave excellent presentations and nearly everybody in the classroom accepted him as an expert in market research. He drew very good conclusions from the facts and he also could explain a lot of details to the other students. But when it came to the final examination, he failed. I was really surprised.' My colleague finished. What happened? Typically we would think that the student may have had some problems in writing tests or that he had had a bad day. Therefore we addressed this mismatch 
comparing our experience of the student as a good learner in the classroom to the test results-but what happens if we look at the teacher? There are two possibilities: the teacher may have misjudged the student in the classroom or the test did not test what it was designed to do. If we assume that the teacher did not misjudge the student in the classroom because all the other students had the same impression, we have to take a closer look at the second alternative. We usually assume that our tests are designed pretty well to test the competencies of students and we would seldom doubt it.

\section{Tests and judgments}

To see what a test really does, let us use the example of the very famous test, the so-called Turing test, which was invented by Alan Turing. Turing designed the test to figure out whether there could ever be a machine created with artificial intelligence. Imagine a small room with a big curtain in the middle. Behind the curtain there is something that we do not know. Some experts are sitting in front of the curtain. These experts have to ask questions to the 'something' behind the curtain. After a while these experts have to say whether the 'something' behind the curtain is a machine or a human being or whether this question is to remain unanswered. If they belief that there is a human being behind the curtain but it is a machine then we could say the machine has some artificial intelligence. However, in accordance with Heinz von Foerster we could also think that this test does not test the machine. It only tests whether the experts are able to distinguish a machine from a human being and if they are not able to do so, they failed the test.

In the case of our student in the market research class we also could have designed a wrong test for his final examination. On the other hand we could have misjudged him during the course. One thing we know for sure: we did not understand the student. In research we typically never judge things without understanding them-and in the classroom? We typically judge our student's answers positively if they are close to the answer we would give to certain question. However, this may not be their answer. Often we do not even try to understand the answers that we judge as wrong. If we do not question our judgments we do not step into the process of understanding the students' thoughts. The only thing we typically want is that the students understand our thoughts. This is even more true at school. The students there are typically trivialized in the following sentence, students are judged positively if they give the teacher's answers. They are judged negatively if their answer does not fit the teacher's answer. Therefore the only thing students learn is to reproduce answers. Yet, still we all agree the goal for our students should to be educated to become independent thinkers. How then should they produce independent thoughts if they do not have the opportunity to produce independent answers. In producing independent and unexpected answers they produce independent thoughts. These independent thoughts lead to creativity and innovation. If a teacher has to evaluate an answer as right or wrong they have to evaluate it using their own thoughts. An independent thought is by definition independent from the stimulus and therefore unpredictable and therefore untestable. If we use tests in our classrooms that do not allow students to use independent thinking, we 'trivialize' our students and they give us answers that are predictable and therefore also trivial. Therefore students and teachers may be disappointed when using the behavioristic approach to create an atmosphere for independent and creative thinking. One may argue that even for independent thinking the students need some content. If their students need content who else should give it to them other than the teacher? So one may argue that teachers are so important because they have to transfer the content and with it the knowledge which is so important for independent thinking-'even in phrasing their questions the students struggled to find the appropriate business school cubbyhole in which to place every conceivable business situation. Then, as if by turning a crank, they expect the appropriate solution to pop up. Obviously neither people nor problems fit molds, and the very act of trying to make 
them do so distorts perceptions. ${ }^{32}$ Yet still the students who like independent thinking remain disappointed-but why?

\section{Words as containers of goods}

According to Heinz von Foerster the answer is easy: 'No wonder that an educational system that confuses the process of creating new processes with the dispensing of goods called "knowledge" may cause some disappointment in the hypothetical receivers, for the goods are not coming: there are no goods'. ${ }^{33}$ In the 'Aktionsprogramm' for the $21^{\text {st }}$ century the German government refers to the rapid growth of knowledge and to an explosive increase of knowledge. In this very typical wording in the area of knowledge, knowledge is seen as totally independent from people. This is simply not true. Knowledge may be a result of a hard-working process called information, but also the term 'information' is typically used as a good, although it is a process conducted by people. Furthermore it is an active process for the one who wants to get the information. If we think about knowledge and information as a good, we typically refer to the transmission approach in which knowledge and information can be transmitted to the student, but we know that teaching cannot be done without learning. Whatever we do and whatever we present to the student, if they do not want to learn we have no chance of succeeding. In other words: learning is not delegable. The teacher cannot do it for the student. The only thing that the teacher can do is to support the student in their learning process, but we know that it is possible to learn without a teacher. People who do this are called autodidacts. According to the constructivist approach the role of the teacher is to support the autodidactic capabilities of the students. To do so, the teacher has to look more closely at the learning process instead of investigating only the teaching process. In the typical school environment as well as in the typical university environment the focus in education is on teaching and the curriculum where-as in the constructivist approach the focus lies on the students and the learning process which can be supported by the environment and by the teacher.

\subsection{Constructivist Approach}

\section{What is constructivism about?}

It is an unconventional approach to the problems of knowledge and knowing. It starts from the assumption that knowledge, no matter how it be defined, is in the heads of persons, and that the thinking subject has no alternative but to construct what he or she knows on the basis of his or her own experience. What we make of experience constitutes the only world we consciously live in. It can be sorted into many kinds, such as things, self, others, and so on. But all kinds of experience are essentially subjective, and though I may find reasons to believe that my experience may not be unlike yours, I have no way of knowing that it is the same. The experience and interpretation on language are no exception. ${ }^{34}$

The constructivist perspective challenges the dominant view of knowledge acquisition, objectivism. The objectivist view is built on the idea that reality exists independently of the observer and can be 'discovered' through the use of a series of systematic steps to achieve verifiable facts about the external 'real' world. Objectivism gives rise to a behavioral view of teaching and learning. In contrast, the constructivist perspective views knowledge as a form of mental representation, a construction of the human mind. Constructivism has been overshadowed by objectivism in western thought. This is largely because objectivism lends itself to the implementation of mechanical processes and is therefore efficient and functional. The constructivist perspective is a powerful framework for understanding how individuals organize experience and what they believe to be reality. ${ }^{35}$ 
The following categories are used to organize a discussion of features of the constructivist view: (1) Reality, (2) Knowledge, (3) The Purpose of Knowing, (4) The role of the Learner, and (5) The role of the Teacher.

1. Reality. Reality does not exist separately from the observer, 'out there', needing only to be discovered. There are many forms of reality, each depending on the observer's frame of reference and interaction with the observed.

2. Knowledge. Knowledge consists not merely of the facts, principles, and theories deduced from observations of phenomena and events. Knowledge includes the ability to use information in meaningful ways and encompasses thoughts, feelings, and interpretations. Knowledge involves an ongoing interpretation of the meaning of events and phenomena.

3. The Purpose of Knowing. The purpose of knowing is not the discovery of reality. The purpose of knowing is adaptive. It serves to guide the organization of reality to successfully organize and cope with one's experience. The purpose of education is not simply the acquisition of information and skills. It includes the development of skills to organize and successfully cope with the world of experience.

4. The Role of the Learner: The role of the learner is not to passively receive information, but to actively participate in the construction of new meaning.

5. The Role of the Teacher: 'The role of the teacher is not to simply present new information, correct students' 'misconceptions', and demonstrate skills. It is to guide the learner to consider new ways of thinking about phenomena and events. In order to do so, the teacher must have some understanding of what the learner brings to the learning experience, that is, his or her prior ideas, thoughts. ${ }^{36}$

Whereas the transmission approach refers to facts and knowledge to be transferred to the students, the constructivists approach refers to understanding. Things which can be derived on 'rational operations, should be understood' ${ }^{37}$ But what does understanding mean? Typically the feeling of understanding arises if the new thought or a new concept matches already existing thoughts or concepts and experiences, even or especially if the latter has to be changed. Using constructivist language we would perhaps say, understanding means to establish or generate a conceptual structure that is viable to one's previous experiences and concepts. 'What determines the value of the conceptual structure is their experiential adequacy, their goodness or fit the experience, their viability as means for the solving of problems, among which is, of course, the never-ending problem of consistent organization that we call understanding. ${ }^{\prime 38}$ This means that understanding changes concepts. It generates a new viable conceptual structure. The term 'viability' is tied to the idea of equilibrium. 'In the sphere of cognition ... equilibrium refers to state in which an epistemic agent's cognitive structures have yielded and continued to yield expected results, without bringing to the surface conceptual conflicts or contradictions. ${ }^{39}$ The feeling of having something understood means to have a good feeling (i.e. equilibrium) with the changes of concepts. We are typically aware that we do not get this feeling as a result of a positive judgment by someone else. We want to have that feeling 'inside'. This also means that another person can never value whether you have understood something or not. You are the only one who can do it. It also means that an answer that may be correct according to your cognition may be wrong to the cognition of someone else. 'Therefore, constructivism asserts that knowledge resides in individuals; that knowledge cannot be transferred in act from the head of the teacher to the heads of students. The student tries to make sense of what is thought by trying to fit it with his or her experience. ${ }^{40} \mathrm{~A}$ summary of the two approaches is given in Table 2 .

In the introduction we defined learning as discovering and developing oneself. Now we can add that this has to be done on two dimensions: the first behavioral, the second conceptional. For our purposes we would now define learning as discovering and developing one's behavior as well as discovering and 
Table 2. Comparison of transmission approach and constructivist approach

\begin{tabular}{|c|c|c|}
\hline & Transmission approach & Constructivist approach \\
\hline Knowledge & Transferable good & The end of a constructive process \\
\hline Information & Good & Process \\
\hline Teaching & Transferring knowledge & Supporting learning \\
\hline Goal of education & Broad knowledge & Autonomy, the ability of self-governing \\
\hline Role of learner & Passive consumer & Active producer \\
\hline Role of teacher & Transmitter of content & Assistant of the learner \\
\hline Task of tests & Test the learner & Test the teacher \\
\hline $\begin{array}{l}\text { Sources of } \\
\text { information }\end{array}$ & Teacher, Textbooks & All sources available \\
\hline $\begin{array}{l}\text { Inducement for } \\
\text { getting } \\
\text { information }\end{array}$ & Curriculum & Student's demand \\
\hline $\begin{array}{l}\text { Who is governing } \\
\text { the learning } \\
\text { process? }\end{array}$ & Teacher & Student \\
\hline Interaction between & Teacher, Student & Students \\
\hline Activities & $\begin{array}{l}\text { Listening, reading, } \\
\text { memorizing }\end{array}$ & Doing, thinking, talking \\
\hline
\end{tabular}

developing one's own concepts. Discovering as well as developing on both dimensions is an active process. There are two ways of developing or changing behavior. The first is to change your behavior only because other people tell you to do so and perhaps they give you an incentive. So the change of behavior comes from outside and is described by behaviorism. The second way of changing behavior is due to the change in concepts and that means a change in your insights. The change in concepts does not always lead to a change in behavior; it 'only' sometimes leads to a change in perception. If we, for example, give an answer to a question that we have not understood, and we would not give it without the question, it is a change of behavior but not a change of concept. From school we all know that we sometimes gave answers that were totally correct according to our concepts but not to the teacher's expectation, i.e. their concepts. Nearly everybody knows the situation where the teacher wants to hear a special answer to a question and where the student knows the answer but has not understood it. They were clever enough not to betray it, but the teacher judged it positively, and the opposite is also well known, where the teacher says 'wrong' even if the student was absolutely sure that their answer was correct. It is obvious that the first approach is dominant at school as well as at university and especially in classical business programs and does not meet the requirements discussed in entrepreneurship education literature cited above. If not at (business) school, where else can we find the way of learning that meets the requirements?

\section{An Appropriate Learning Environment}

'Children are full of ideas. But then after some years of going to school this ends, because they are pressed into a corset, which does not fit' (Artur Fischer, Inventor of the Fischer dowel). Children's life is full of playing. When they come to school, we believe that life must become more serious and in order for children to make progress in their learning activities. We encourage them more to learn rather than to play, but playing is an excellent learning activity. The link between learning and playing is 'interest', which stems from the Latin word 'inter' and 'esse' and means 'to be in between'. That is true for playing and is the best for learning. So interest is the serious link between playing and learning. If playing is done with interest and enthusiasm it is serious learning. This lays the ground for lifelong learning. 'Lifelong learning on ones own means, it is left to the individual learner, what, how, where 
and when he or she learns. ${ }^{41}$ Do we learn lifelong learning (self-directed learning) at school? The answer is obviously not very much, because it is not left to the student what, how, where and when he or she learns but to the teacher and to the curriculum. 'Self-directed learning at school refers at best only to the "how" but not to the "what", "where", etc.' 42 Schools aside, where are these environments for self-directed learning? Learning environments in general are all environments in which we learn. Now we are looking for learning environments where self-directed learning is supported.

Furtner-Kallmünzer et al. (2002) ${ }^{43}$ investigated the out-of-school-learning of children aged between 10 and 14. Their results are impressive. They show the value of out-of-school-playing and learning. Children are self-directed learners during their spare time. They do not focus on learning but on fun. Nevertheless they only have fun if they feel that their competencies are increasing, i.e. they have fun as a result of learning without focusing on learning. This way of learning is both effective and efficient. Here are some of their results:

From an educational policy point of view, spare time as a self-organized field of life is an indispensable learning environment. This learning environment offers a high educational value (e.g. development of self-organizing skills, development of lifelong learning, and development of social competence in the peer group) even if the appropriateness of the single activities is still disputed by parents and teachers. ${ }^{44}$

These competencies and skills are obviously important for entrepreneurs, ${ }^{45}$ and they are supported and developed more in spare time than in school. In addition, one of the recommendations of Faltin to improve an entrepreneurial environment is: 'Reorganizing work into fun'. Is that serious enough? The finding of Hössl gives us a new insight: 'Because fun depends on the increase of competencies, all children are interested to learn in exercising their spare time'. ${ }^{46}$

Learning is a precondition for fun. If we see children having fun exercising their activities, we can be sure, that these children are learning. Furthermore, 'Children do not only get many insights and competencies in exercising their interests, but they also get the required qualifications for the learning process like, e.g. concentration, sticking to rules, skillfulness, timing, staying power, creativity' ${ }^{47}$

It seems that we totally underestimate the value of playing and having fun for the purpose of learning, especially in learning entrepreneurial skills and competencies or characteristics. In general, if you are really interested in something you do not perceive your endeavors as work or learning but as fun! Achievement and fun is no contradiction, as typically can be seen in the field of successful entrepreneurs.

There is evidence on the hypothesis that in preparing for lifelong learning as well as for independent thinking and acting the out-of-school environment is more helpful compared to the environment in school. Or, as Faltin puts it: 'Our educational system, as it is, seems not to facilitate an adequate approach towards entrepreneurship, maybe not towards real life in general. ${ }^{\prime 48}$

Even if some schools are on their way to the right side of Table 3, it still describes the mainstream of in-school and out-of-school learning.

When comparing Tables 1, 2 and 3 it becomes obvious that the demands for an entrepreneurship education, the constructivist approach and the out-of-school learning environment coincide. As shown in Table 4, the constructivist paradigm serves as a theoretical base for entrepreneurship education and the out-of-school learning environment assures that it can be put to practice.

Now, having a paradigm and knowing that we can put it into practice, we can then draw conclusions on entrepreneurship education settings that can be used to design an entrepreneurship education program. 
Table 3. Comparison of in-school learning and out-of-school learning

\begin{tabular}{|c|c|c|}
\hline & In-school learning & Out-of-school learning \\
\hline Knowledge & Transferable good & $\begin{array}{l}\text { The end of a constructive ongoing } \\
\text { process }\end{array}$ \\
\hline Information & Good & Never ending Process \\
\hline Teaching & Transferring knowledge & Learning without teaching \\
\hline Goal of education & Broad knowledge & $\begin{array}{l}\text { Autonomy, the ability of self- } \\
\text { governing achieved in having fun }\end{array}$ \\
\hline Role of learner & Passive consumer & Active producer \\
\hline Role of teacher & Transmitter of content & $\begin{array}{l}\text { Assistant of the learner fulfilled by } \\
\text { parents or peers }\end{array}$ \\
\hline Task of tests & Test the learner & No tests but real life \\
\hline Sources of information & Teacher, Textbooks & All sources available \\
\hline $\begin{array}{l}\text { Inducement for getting } \\
\text { information }\end{array}$ & Curriculum & Student's demand \\
\hline $\begin{array}{l}\text { Who is governing the } \\
\text { learning process? }\end{array}$ & Teacher & Student \\
\hline Interaction between & Teacher, student & Students \\
\hline Activities & Listening, reading, memorizing & Doing, thinking, talking \\
\hline
\end{tabular}

\section{Principles for Designing an Entrepreneurship Education Program}

Now we are going to draw up a set of principles that should help to design an entrepreneurial learning environment in which students can mostly govern their own learning process. These principles do not cover any content because the themes that may accrue during the learning process and may be demanded by the students can be found in several sources and are well known by entrepreneurship teachers. According to our experience these principles help create a learning environment for a student-governed learning process which supports autonomy, self-reliance, independent thinking and in general the ability of self-governing.

We also have to add some water to the wine. If children do not to practice innovative and independent thinking early enough we cannot close that gap by starting at the age of 18 or 20, i.e. at university.

Especially the understanding and the thinking about technology has to be produced between the ages of 8 and 16, because during that period children develop their ability to think concretely and more important, abstractly, ${ }^{49}$ which is helpful for technologically based creativity.

If children lack experience in mechanical, technical and electronic devices they cannot develop creativity solving technological problems. Obtaining experience does not mean learning to handle devices-it does mean disassembling devices. If children disassemble their toys (and we know they enjoy doing it) they learn more compared to just playing with their toys. Children love to 'repair' their broken toys because then they 'are allowed' to disassemble them. From that perspective the best toys are toys that can be assembled and disassembled. In doing so, children can construct their own concepts of mechanical and electronic issues, which they can apply to new problems for new solutions.

If children have some of the abovementioned experiences they have a good grounding that we can use in higher education to foster this learning through disassembling and assembling by adding a reflection process to deepen the knowledge of the students. The following principles are derived from the constructivist perspective as well as from the insights of the out-of-school learning environment to support the ability of self-governing. 
Table 4. Comparison of three streams of literature

\begin{tabular}{|c|c|c|c|}
\hline & $\begin{array}{l}\text { Entrepreneurial } \\
\text { education }\end{array}$ & $\begin{array}{l}\text { Constructivist } \\
\text { approach }\end{array}$ & $\begin{array}{l}\text { Out of school } \\
\text { learning }\end{array}$ \\
\hline Knowledge & Process & $\begin{array}{l}\text { An ongoing } \\
\text { constructive process }\end{array}$ & $\begin{array}{l}\text { An ongoing } \\
\text { constructive } \\
\text { process }\end{array}$ \\
\hline Teaching & Supporting learning & Supporting learning & Supporting learning \\
\hline Goal of education & $\begin{array}{l}\text { Learning to live, } \\
\text { autonomy, the ability } \\
\text { of self-governing }\end{array}$ & $\begin{array}{l}\text { Autonomy, the ability } \\
\text { of self-governing }\end{array}$ & $\begin{array}{l}\text { Autonomy, the } \\
\text { ability of self- } \\
\text { governing } \\
\text { achieved in } \\
\text { having fun }\end{array}$ \\
\hline Role of learner & Active producer & Active producer & Active producer \\
\hline Role of teacher & Assistant of the learner & Assistant of the learner & $\begin{array}{l}\text { Assistant of the } \\
\text { learner fulfilled } \\
\text { by parents or } \\
\text { peers }\end{array}$ \\
\hline $\begin{array}{l}\text { Sources of } \\
\text { information }\end{array}$ & All sources available & All sources available & All sources available \\
\hline $\begin{array}{l}\text { Inducement for } \\
\text { getting information }\end{array}$ & Student's demand & Student's demand & Student's demand \\
\hline $\begin{array}{l}\text { Who is governing the } \\
\text { learning process? }\end{array}$ & Student & Student & Student \\
\hline Interaction between & $\begin{array}{l}\text { Students, teacher is not } \\
\text { excluded }\end{array}$ & Students & Students \\
\hline Activities & Doing, thinking, talking & $\begin{array}{l}\text { Doing, thinking, } \\
\text { talking }\end{array}$ & $\begin{array}{l}\text { Doing, thinking, } \\
\text { talking }\end{array}$ \\
\hline
\end{tabular}

\section{Principles for entrepreneurship education}

Principle 1: As a general direction it is useful to have an image of a piano tutor or a driving instructor rather than that of a lecturer. Help the student to develop their abilities into competencies.

We would never expect a piano player or driver to be competent just through reading books and making presentations. We would expect them to practice and to reflect. In the constructivist perspective experience plays an important role. So we think that undergoing an activity is a good starting point for creating experience and a basis for reflection. We found, that starting with an activity/experience helps students to ask good questions. If these questions are discussed in an open discourse, the students can reflect on their experience and create new knowledge. During the reflection process the teacher can play an important role in supporting the student's learning process. During that process teachers should not give answers but they should address questions so that students can create answers. Creating answers will support ownership of thoughts and development of own concepts, more than accepting the answer the teacher has given. So putting the students in the driver's seat typically creates a self-governed learning process. The more passive the role of the teacher is, during the experiential phase, the more the students can 'assemble and disassemble' and develop own ideas and concepts.

Principle 2: Let students develop their own learning goals. Give them support. 
A self-governed learning process also covers the development of learning goals. The student will not do it as an isolated individual but based on their experience and relationships with others. If the student develops their own learning goal we found that they are more motivated, more interested and feel more responsible for reaching their own goal.

Usually students at first have some difficulties in defining their learning goals. To support them it may be reasonable to take leaf out of someone's book and describe what they are interested in. As in business, these goals typically have to be developed through the learning process.

Principle 3: Derive the content to be covered from the problems and learning goals identified by the students.

If the content is offered 'on demand', the students are more interested in it than if they had to read it on the syllabus. If the students demand content, it is their content and not the teacher's content.

Principle 4: Do not test students in the classical way.

We discussed the problems of tests earlier in this article. If one thinks about the relationship between an athlete and their trainer, nobody would expect the trainer to conduct an examination for his prote'ge'. They both prepare the athlete for a real competition that serves as a test. Therefore the athlete and the trainer can fight together against the competition. The athlete's point of view is never one of fighting against the trainer's test. If teachers want to become their students' coach, they should have the same 'foe image' and fight the same challenge. If the student gets the impression that they preparing for a test in which they fight 'against' the teacher's knowledge, it dilutes the relationship between the teacher as a coach and the student. In that sense it is better to set up a competition with clear rules between the students and an external evaluation. Especially if students construct technical devices the functioning of those devices is enough of a test and one can be sure that students want them to work.

Principle 5: Design activities that require interaction and sociocognitive conflict.

Typically if we conduct group work, we want the students to work cooperatively and harmoniously. If students have to argue their thoughts, ideas and opinions against others, this interaction and talking helps them to get a precise idea of their own thoughts. Sociocognitive conflict is shown to be important for sharpening thoughts and ideas in explaining and arguing. It stimulates logic. ${ }^{50}$ This principle is easier to demonstrate if the students are working on technical devices. This is better than any argument. However just arguing does not work if the device does not work. The most important issue of principle 5 is that students must demonstrate their willingness to learn from the experience of doing.

Principle 6: Ensure an open information flow between everybody in the classroom.

Do not control the information flow between students; do not even monitor it. Open access to all kinds of information. Do not restrict it to a special content area.

Principle 7: Information that can be used and combined in different ways encourages students to consider the world of opportunities.

It is often argued that entrepreneurship among others means to grasp opportunities. To discover the opportunities can mean 'to see a new potential in something which is already known'. ${ }^{51}$ Reframing information can lead to new solutions or new ideas. That is especially helpful if it is taken out of the box that is typically used for specific knowledge. An example of this kind of combining of well known knowledge is the new Ixo Cordless screwdriver invented by Bosch. They combined the well-known cordless screwdriver with lithium ion batteries commonly used in cell-phones and mp3-players. Bosch sold more than 1.5 million of these new cordless screwdrivers within the first year. 
Principles 6 and 7 should not be a problem with modern technology, because information is easier to obtain, even though students sometimes do not get it when they need it. If there is an open flow of information in the classroom, students can discuss the information to get an individual and mutual understanding.

Principle 8: Do not show how to solve problems and do not say that an answer is correct or incorrect.

Governing the reflection process with questions will lead the students to their answer. In doing so, they will be able to argue their answer because they have developed it on their own and have not taken it from the teacher. If students have to create a technical device and they realize a problem in their solution, the most important issue is to address the problem from different perspectives. Here the teacher's role is to open ways of 'new' thinking with addressing the problem from different perspectives and to even question the problem as stated by the student.

Principle 9: Support autonomy. It supports ethical thinking and behavior as well as responsibility.

First, autonomy is usually understood as a right of an individual or group. According to Piaget, we understand autonomy as an ability to be self governing. Let us look at two examples given by Kamii:

An unusual example of moral autonomy is the struggle of Martin Luther King, Jr for civil rights. King was autonomous enough to take relevant factors into account and to conclude that the laws discriminating against African Americans were unjust and immoral. Convinced of the need to make justice a reality, he worked to end the discriminatory laws, in spite of the police, jails, dogs, water hoses, and threats of assassination used to stop him. Morally autonomous people cannot be manipulated with reward and punishment. ${ }^{52}$

... Children ... tended to answer that one has to lie to adults sometimes, but it is rotten to do it to other children. When asked for an explanation, the more autonomous children said that breaking the bond of mutual trust is worse than being punished. For autonomous people, lies are bad independently of the reward system, adult authority, and the possibility of being caught. ${ }^{53}$

If we feel self-confident, we think that we do not need moral rules from others because we feel ethically good. If on the other hand we realize we lack self-confidence, we are susceptible for any kind of guidelines. People feel more responsible for what they have created themselves compared to that what they have taken from others.

Principle 10: Have fun in working with the students and light the fire of learning and thinking that is in them.

We used these principles for designing an entrepreneurial program. We evaluated this program from the student's perspective. We found some interesting results that prove the entrepreneurial course superior to other learning environments investigated.

The students do not only work harder and more motivated, they also enjoyed the learning process significantly more compared to classical environments. We also could exclude an impact of the grades onto the students' evaluation, meaning that the superiority of the course is independent of the grades. In addition we found that the students got more insights into entrepreneurship compared to the other learning environments. ${ }^{54}$ 


\section{Acknowledgement}

I would like to thank Markus Maier, Daniel Markgraf, James Parsons and two anonymous reviewers for their helpful comments.

\section{Notes and References}

1. G. Faltin, Creating a culture of innovative entrepreneurship, Journal of International Business and Economy, 2, 2001, p. 123.

2. J. O. Fiet, The pedagogical side of entrepreneurship theory, Journal of Business Venturing, 16, 2001, pp. 101-117.

3. H. G. Frank, Kybernetische Grundlagen der Pädagogik (Stuttgart, Kohlhammer, 1971); H. Löbler, Bestimmung und Kontrolle von Lernzielen und Lerninhalten dargestellt am Beispiel nichtuniversitärer Marketing-Ausbildung, Jahrbuch der Absatz-und Verbrauchsforschung, 30, 1984, pp. 68-83.

4. F. G. Alberti, S. Sciascia \& A. Poli, The domain of entrepreneurship education: key issues, International Journal of Entrepreneurship Education, 2, 2005, pp. 453-482.

5. H. Löbler, M. Maier \& D. Markgraf, Evaluating the constructivist approach in entrepreneurship education, in: Proceedings of the 2005 IntEnt Conference, Surrey, UK, forthcoming.

6. G. T. Solomon, S. Duffy \& A. Tarabishy, The state of entrepreneurship education in the United States: a nationwide survey and analysis, International Journal of Entrepreneurship Education, 1, 2002, pp. 1-22.

7. D. F. Kuratko, Entrepreneurship education: emerging trends and challenges for the 21st century, USASBE, Coleman white paper, http://www.usasbe.org/pdf/CWP-2003-kuratko.pdf, 2003.

8. J. A. Katz, The chronology and intellectual trajectory of American entrepreneurship education 18761999, Journal of Business Venturing, 18, 2003, pp. 283-300.

9. Alberti et al., op. cit., Ref. 4.

10. H. S. Rasheed, Developing entrepreneurial characteristics in youth: the effects of education and enterprise experience, COBA University of South Florida, http://www.coba.usf.edu/ departments/management/faculty/rasheed/research.htm, 2003.

11. Ibid.

12. J. Chamard, Public education: its effect on entrepreneurial characteristics, Journal of Small Business and Entrepreneurship, 6, 1989, pp. 23-30.

13. M. L. Kourilsky, Predictors of entrepreneurship in a simulated economy, Journal of Creative Behavior, 14, 1980, pp. 175-198.

14. Fiet, op. cit., Ref. 2., see p. 102.

15. Ibid., p. 107.

16. Ibid.

17. N. F. Krueger \& D. V. Brazeal, Entrepreneurial potential and potential entrepreneurs, Entrepreneurship: Theory \& Practice, 18, 1994, pp. 91-104.

18. M. L. Kourilsky \& W. B. Walstad, Entrepreneurship and female youth: knowledge, attitudes, gender differences, and educational practices, Journal of Business Venturing, 13, 1998, pp. 77-88.

19. G. Gorman, D. Hanlon \& W. King, Some research perspectives on entrepreneurship education, enterprise education and education for small business management: a ten-year literature review, International Small Business Journal, 15, 1997, pp. 56-77.

20. Solomon et al., op. cit., Ref. 6.

21. H. H. Stevenson, Why entrepreneurship has won, USASBE, Coleman white paper, http://www.usasbe.org/pdf/CWP-2000-stevenson.pdf, 2000, p. 6.

22. R. Ronstadt, The educated entrepreneurs: a new era of entrepreneurial education is beginning, in: C. A. Kent (Ed.), Entrepreneurship Education (New York, Quorum Books, 1990), pp. 69-88.

23. S. Parker, Learning about the unknown: how fast do entrepreneurs adjust their beliefs?, Journal of Business Venturing, 2005 (forthcoming).

24. R. H. Cantwell, Learning theory for academics: an introductory model, The On-line Journal of the Information and Education Services Division, University of Newcastle, Available from: http://www.newcastle.edu.au/oldsite/services/iesd/publications/eunexus/articles/teaching_guides/le arning_theory/learningtheory_1.htm, 2001 (Accessed 15 March 2004)

25. The classroom of the future, Newsweek, 138 (18), 29 October 2001, p. 60. 
26. G. D. Meyer, Major unresolved issues and opportunities in entrepreneurship education, USASBE, Coleman white paper series, Available from: http://www.usasbe.org/pdf/CWP-2001-meyer.pdf, 2001 (Accessed 15 March 2004).

27. D. F. Kuratko, The emergence of entrepreneurship education: development, trends, and challenges, Entrepreneurship: Theory \& Practice, 29, 2005, pp. 577-597, p. 590.

28. M. Laukkanen, Exploring alternative approaches in high-level entrepreneurship education: creating micro-mechanisms for endogenous regional growth, Entrepreneurship \& Regional Development, 12, 2000, pp. 25-47, p. 28.

29. E. von Glasersfeld, Radical constructivism and teaching, Scientific Reasoning Research Institute, University of Massachusetts, 2000.

30. Ibid.

31. Ibid.

32. M. H. McCormack, What They Don't Teach You at Harvard Business School (New York, Bantam Dell, 1984).

33. H. von Förster, Perception of the future and the future of perception, Instructional Science, 1, 1971, pp. 31-43.

34. E. von Glasersfeld, Radical Constructivism: A Way of Knowing and Learning (London, Falmer Press, 1995).

35. B. L. Shapiro, What Children Bring to Light (New York, Teachers College Press, 1994).

36. Ibid.

37. Von Glasersfeld, op. cit., Ref. 28.

38. E. von Glasersfeld, Learning as a constructive activity, in: J. C. Bergeron \& N. Herscovics (Eds), Proceedings of the 5th Annual Meeting of the North American Chapter of the International Group for the Psychology of Mathematics Education (Montre'al, Psychology of Mathematics Education, North American Chapter, 1983), pp. 41-69.

39. Ibid.

40. A. Lorsbach \& K. Tobin, Constructivism as a referent for science teaching, in: F. Lorenz, K. Cochran, J. Krajcik \& P. Simpsons (Eds), Research Matters to the Science Teachers, Monograph No. 5 (New York, NARST, 1992).

41. Sachverständigenrat Bildung, Wege zur Bildungsreform - Chancen, ein neues Leitbild zu verwirklichen, Hans-Böckler-Stiftung, Diskussionspapier, Available from: http://www.lernende-regionzollernalb.de/contentbuilder/uploads/files/43/BcklerDiskussionspapier_6.pdf, 2001 (Accessed 15 March 2004), p. 9.

42. J. Lipski, Was lernen Kinder in der Freizeit?, in: W. E. Fthenakis \& M. R. Textor (Eds), Das OnlineFamilienhandbuch (article in: www.familien-handbuch.de, 2002), p. 123.

43. M. Furtner-Kallmünzer, A. Hössl, D. Janke, D. Kellermann \& J. Lipski, In der Freizeit für das Leben lernen (München, VS-Verlag für Sozialwissenschaften, 2002).

44. A. Hössl, D. Janke, D. Kellermann \& J. Lipski, Freizeitaktivitäten und Freizeitlernen, in: M. FurtnerKaltmüller, D. Janke, D. Kellermann \& J. Lipski (Eds), In der Freizeit für das Leben lernen (Opladen, Leske + Budrich, 2002), p. 218.

45. Faltin, op. cit., Ref. $1 ;$ J. O. Fiet, The theoretical side of teaching entrepreneurship, Journal of Business Venturing, 16, 2000, pp. 1-24.

46. Hössl et al., op. cit., Ref. 43.

47. Faltin, op. cit., Ref. 1, p. 216.

48. G. Faltin, Competencies for innovative entrepreneurship, in: Adult Learning and the Future of Work (Hamburg, UNESCO Institute for Education, 1999).

49. J. Piaget \& B. Inhelder, The Psychology of the Child (New York, Basic Books, 1969).

50. C. Kamii, Young Children Reinvent Arithmetic (New York, Teachers College Press, 2000), p. 46.

51. Faltin, op. cit., Ref. 1.

52. Kamii, op. cit., Ref. 49, p. 57.

53. Ibid., p. 58.

54. Löbler et al., op. cit., Ref. 5, p. 9. 